\title{
Development of a real time quantitative PCR assay for the hard clam pathogen Quahog Parasite Unknown (QPX)
}

\author{
M. Maille Lyons ${ }^{1}$, Roxanna Smolowitz ${ }^{2}$, Christopher F. Dungan ${ }^{3}$, \\ Steven B. Roberts ${ }^{2, *}$ \\ ${ }^{1}$ Department of Marine Sciences, University of Connecticut, 1080 Shennecossett Road Groton, Connecticut 06340, USA \\ ${ }^{2}$ Marine Resources Center, Marine Biological Laboratory, 7 MBL Street, Woods Hole, Massachusetts 02543, USA \\ ${ }^{3}$ Maryland Department of Natural Resources, Cooperative Oxford Laboratory, 904 S. Morris Street, Oxford, \\ Maryland 21654, USA
}

\begin{abstract}
Quahog Parasite Unknown (QPX) is a thraustochytrid pathogen responsible for catastrophic mortalities of the northern quahog (hard clam) Mercenaria mercenaria. A real-time quantitative polymerase chain reaction (qPCR) assay was developed to assist research efforts on QPX ecology and pathology. Sensitivity of the assay was evaluated with serial dilutions of QPX-cultured cells to determine the lowest concentration of DNA that remained detectable in both the presence and absence of extraneous environmental substances. QPX cells were quantified before DNA extraction to calibrate standard curves to cell counts. Based on our results, the qPCR assay is able to quantify QPX within the range of 1 to several thousand organisms per reaction. Specificity of the assay was assessed by testing 29 thraustochytrid-like protists isolated from suspension-feeding bivalves from China, Oregon, Maryland, and Virginia. Application of the assay was demonstrated with positive qPCR results from naturally contaminated environmental samples including marine aggregates (i.e. marine snow), clam pseudofeces, and inflammatory nodules from infected clams. This quantitative assay for QPX will provide a valuable tool for characterizing QPX parasite abundances in coastal environments and for improving clam disease diagnostics.
\end{abstract}

KEY WORDS: Quahog Parasite Unknown • QPX · Thraustochytrids • Mercenaria mercenaria • Real-time PCR $\cdot$ Histology $\cdot$ Marine aggregates $\cdot$ Pseudofeces $\cdot$ Clams

\section{INTRODUCTION}

Quahog Parasite Unknown (QPX) is a pathogen of the suspension-feeding bivalve mollusc Mercenaria mercenaria, commonly called a quahog or hard clam. The parasite was first called QPX (Whyte et al. 1994) in a paper describing the pathology associated with significant clam mortalities that occurred in 1989 in a Canadian hatchery on Prince Edward Island. The authors found the parasite to be identical to an unnamed organism that caused earlier (1959 to 1962) mass mortalities of clams at Neguac, New Brunswick in the estuary and in cold storage (Drinnan \& Hender- son 1963). The first published reports of QPX outbreaks in the United States followed large-scale clam mortalities at Cape Cod, Massachusetts (Smolowitz et al. 1998). The authors described a 4 yr history (1992 to 1996) of chronic, severe mortalities of cultured clams from 2 locations. Morbid clams were histologically positive for an endosporulating protist similar to that observed in the Canadian hatchery. By 1996, researchers in Virginia began surveying hard clam populations and subsequently discovered the presence of QPX in cultured clams as far south as Virginia's Eastern Shore (Ragone-Calvo et al. 1998). In 2002, a QPX outbreak in wild populations of clams in New York was 
recorded (Dove et al. 2004). These large-scale mortality events in both cultured and wild clam beds have devastated parts of the hard clam shellfishing industry. QPX remains a primary concern for regulators because there are several clam-growing areas within the range of QPX (i.e. Canada to Virginia) that have not experienced clam mortalities due to QPX.

QPX is broadly classified with the thraustochytrids (Maas et al. 1999, Ragan et al. 2000, Stokes et al. 2002), a group of elusive marine protists common in coastal environments (Raghukumar 2002). They are facultative parasites recently detected embedded within marine aggregates (i.e. marine snow) collected from clam-growing coastal waters affected by QPX outbreaks (Lyons et al. 2005). In the environment, marine aggregates are aspirated through the inhalant siphon of the clam during normal feeding processes, and are thought to facilitate entry of this microscopic pathogen into its benthic host. Marine aggregates have been identified as a possible target for environmental surveillance of QPX (Lyons et al. 2005). However, ecological disease research is hindered because there is no quantitative detection technique to enumerate the number of QPX parasites in environmental samples.

The primary diagnostic method for QPX infections in clams is histological analysis (Howard et al. 2004). This procedure cannot be used for environmental samples such as seawater, sediment, macrophytes, or marine aggregates. Conventional molecular diagnostic methods have been developed to detect the QPX parasite, including the application of DNA probes for PCR and in situ hybridization (Stokes et al. 2002). The PCR assay described for clam tissues targets small-subunit ribosomal DNA (SSU rDNA). While effective at detecting QPX, this assay targets the relatively conserved SSU rDNA region, limiting the differential specificity of the test. This is of particular concern in analysis of samples containing a potentially large number of unidentified, related species. In addition, conventional end-point PCR has lower resolution, is less precise, and requires transferral of post-PCR products, which provides opportunity for cross-contamination. Finally, although PCR identification of QPX organisms has provided new and important information on potential exposure of clams to environmental sources of pathogenic organisms, there is still a need to quantify QPX abundances in environmental samples in order to identify any potential threshold level needed to initiate the disease.

We report the development of a 1-step SYBR Greenbased quantitative real-time PCR (qPCR) assay for the sensitive detection of QPX and the validation of the assay's effectiveness with naturally contaminated environmental samples. Real-time PCR assays for detection of other marine microorganisms have been reported, including assays for toxic dinoflagellates (Bowers et al. 2000, Gray et al. 2003, Galluzzi et al. 2004), human pathogens (Guy et al. 2003, Myers et al. 2003, Panicker et al. 2004), and pathogens of other bivalve molluscs (Audemard et al. 2004). In order to enhance the QPX qPCR assay, unique aspects were incorporated into its development, including a pathogen-spiked marine aggregate dilution series to demonstrate applicability with environmental samples and the use of an electronic particle counter to obtain absolute quantitative results. This assay is the first quantitative test for QPX and shows the greatest promise in characterizing the abundances of this economically important pathogen in the environment. In addition, this is the first report of QPX in the pseudofeces of Mercenaria mercenaria, which supports the hypothesis of disease transmission via the feeding processes of the clam host.

\section{MATERIALS AND METHODS}

QPX strain and preparation of dilution series. The QPX strain (ATCC 50749) used in the current study was maintained under routine culture conditions at the Marine Resources Center at the Marine Biological Laboratory, Woods Hole, as previously described by Kleinschuster et al. (1998). To obtain a stock sample for dilution, cultured QPX cells $(12 \mathrm{ml})$ were washed (Anderson et al. 2003) 5 times with sterile seawater ( $0.2 \mu \mathrm{m}$-filtered and autoclaved). The resulting pellet was suspended in sterile seawater and serially diluted over 5 orders of magnitude. The number of QPX organisms in each standard curve datum was determined using an electronic particle counter (Multisizer IIE Beckman-Coulter Counter) equipped with a $140 \mu \mathrm{m}$ aperture tube. The number of particles greater than the $4 \mu \mathrm{m}$ lower size limit of QPX organisms (Smolowitz et al. 1998) was calculated by subtracting background counts of the seawater diluents from the counts for the sample (seawater with the dilution aliquot). A $1 \mathrm{ml}$ aliquot of each dilution was stored at $-20^{\circ} \mathrm{C}$ for DNA extraction.

Pathogen-spiked marine aggregate dilution series. Marine aggregates were collected on a flood tide from intertidal waters historically free of QPX, at the University of Connecticut's Avery Point Campus, using settling cones as previously described by Lyons et al. (2005). Aggregates from $10 \mathrm{l}$ of water were settled and homogenized by vortexing. The consolidated aggregate mixture was divided equally among 6 centrifuge tubes, and each sample was brought to a final volume of $9 \mathrm{ml}$ with sterile seawater. Five of the marine aggregate tubes were spiked with $1 \mathrm{ml}$ of one of the QPXcultured cell serial dilutions and one aggregate tube 
received $1 \mathrm{ml}$ of sterile seawater. A $1 \mathrm{ml}$ aliquot of each dilution series was stored at $-20^{\circ} \mathrm{C}$ for DNA extraction.

Collection and culture of thraustochytrid-like organisms. In order to test the specificity of the QPX qPCR assay, 29 environmental isolates of thraustochytrid-like organisms were evaluated. These isolates were obtained from a variety of suspensionfeeding bivalves including oysters (Crassostrea virginica, C. ariakensis), soft shell clams (Mya arenaria), or hard clams/quahogs (Mercenaria mercenaria) from a range of coastal environments in Maryland, China, Oregon, and Virginia, from 1991 to 2005 (see Table 1). Isolates were originally cryopreserved by freezing axenic cultures to $-196^{\circ} \mathrm{C}$ in a freezing medium (5 to $10 \% \mathrm{v} / \mathrm{v}$ DMSO in culture medium), after slowly freezing $\left(1{ }^{\circ} \mathrm{C} \mathrm{min}^{-1}\right)$ in foam blocks at $-70^{\circ} \mathrm{C}$ (Dungan \& Hamilton 1995). Isolates were aseptically revived from frozen pellets and grown in $10 \mathrm{ml}$ of either DME/F12-3 (Dungan \& Hamilton 1995) or KMEM-10 (Kleinschuster et al. 1998) culture media in $25 \mathrm{~cm}^{2}$, vent-capped tissue culture flasks in a $27^{\circ} \mathrm{C}$ incubator. Cultures were monitored and photographed with an inverted microscope to verify the presence of intact cells. Cells were harvested after $3 \mathrm{~d}$ of growth by centrifuging a $1.5 \mathrm{ml}$ aliquot for $10 \mathrm{~min}$ at $300 \times g$. Cells from each aliquot were stored at $-20^{\circ} \mathrm{C}$ for DNA extraction.

Environmental sampling. In order to test the applicability of the new qPCR assay, 3 types of environmental samples (marine aggregates, clam pseudofeces, and clam tissue nodules) were analyzed. Hard clams ( $\mathrm{n}=16$ ) and marine aggregates (aggregated material settled out of 4 liters of seawater) were collected from Barnstable Harbor, Massachusetts in August 2005. This site had experienced QPX outbreaks in the 2 years prior to sampling (R. Smolowitz unpubl. data). Marine aggregate samples were settled overnight to $3 \mathrm{ml}$ seawater and stored in $1.5 \mathrm{ml}$ aliquots at $-20^{\circ} \mathrm{C}$ for DNA extraction. Clams were transported to the laboratory where they were opened and examined visually for nodules (consisting of QPX organisms and reactive hemocytic inflammation) in mantle and siphon tissues. When observed ( $\mathrm{n}=4$ out of 16 ), nodules were aseptically removed and halved for histological (preserved in fixative) and genetic (stored at $-20^{\circ} \mathrm{C}$ ) analysis. If nodules were not observed during the necropsy, then no tissue sample was obtained for qPCR, even though all 16 clams were subsequently evaluated for QPX infections via histology (i.e. Clams 1 to 12 ; listed as 'no nodule observed' in Table 2). Samples of aggregated material from inside the pallial cavity of all 16 clams (presumed to be pseudofeces) were collected with sterile pipettes and stored at $-20^{\circ} \mathrm{C}$ for DNA extraction. Clams were then fixed in $10 \%$ (v/v) formalin in seawater. Cross sections through the stomach, digestive gland, foot, heart, kidney, mantle, and gill were embedded in paraffin. Tissue sections $(6 \mu \mathrm{m})$ were hematoxylin and eosin-stained (H\&E) (Howard et al. 2004) and examined histologically.

DNA extraction. Genomic DNA was extracted from (1) cultured QPX cell dilution series, (2) QPX-spiked marine aggregate dilution series, (3) cells harvested from thraustochytrid-like protist cultures, and (4) environmental samples (Barnstable Harbor samples) using a Qiagen DNeasy Tissue kit (Qiagen) according to the manufacturer's protocol. Briefly, samples were lysed at $55^{\circ} \mathrm{C}$ for $3 \mathrm{~h}$, washed, precipitated, and eluted with $200 \mu$ of Qiagen's AE buffer. The elution step was increased from $1 \mathrm{~min}$ to $5 \mathrm{~min}$ as recommended (Audemard et al. 2004).

QPX real-time PCR assay. To examine abundances of QPX in samples, genomic DNA was analyzed quantitatively using real-time PCR (Brilliant SYBR Green QPCR Master Mix Kit, Stratagene) in the Opticon Continuous Fluorescence Detection System (Bio-Rad). Primers were designed to amplify a transcript identified from prior QPX differential display analysis (S. B. Roberts \& R. Smolowitz unpubl. data). The forward primer (qpxIRK1; GGAATGTGACGCCGAAAATG) and reverse primer (qpxIRK2; TCCGTATCTCTGAACCCCGATG) amplify a $312 \mathrm{bp}$ product of a targeted transcript, GenBank accession number DV942140. The deduced amino acid sequence of this transcript has significant homology to an inward rectifier potassium channel protein domain (pfam01007) (Marchler-Bauer et al. 2005).

General labyrinthulomycete primers, previously described by Stokes et al. (2002), were also used to confirm that the 29 thraustochytrid-like organisms were closely related (i.e. within the same class: Labyrinthulomycete). The PCR mixtures contained each primer at a concentration of $40 \mathrm{nM}$, Brilliant SYBR Green Master Mix (Stratagene), and $2 \mu$ of template DNA that was first incubated at $95^{\circ} \mathrm{C}$ for $8 \mathrm{~min}$. The qPCR reactions were carried out as follows: $10 \mathrm{~min}$ initial denaturation at $95^{\circ} \mathrm{C}, 50$ cycles of $30 \mathrm{~s}$ denaturation at $95^{\circ} \mathrm{C}, 1 \mathrm{~min}$ annealing at $58^{\circ} \mathrm{C}$ for qpxIRK primers or $50^{\circ} \mathrm{C}$ for general labyrinthulomycete primers (Stokes et al. 2002), and $75 \mathrm{~s}$ extension at $72^{\circ} \mathrm{C}$, with fluorescence measured at the end of every annealing and extension step. Following a 1 min denaturation at $95^{\circ} \mathrm{C}$, melting curve analysis was performed by increasing the temperature from $55^{\circ} \mathrm{C}$ to $95^{\circ} \mathrm{C}$ at a rate of $0.2^{\circ} \mathrm{C} \mathrm{s}^{-1}$, measuring fluorescence every $0.5^{\circ} \mathrm{C}$.

For characterizing phylogeny of thraustochytrid-like strains, primers (Stokes et al. 2002) were used under the same conditions except that the annealing temperature was changed to $50^{\circ} \mathrm{C}$. For all real-time PCR assays, samples were run in duplicate and melting curves were analyzed to verify that no primer dimers 
were formed and that cycle threshold $\left(\mathrm{C}_{\mathrm{T}}\right)$ values represented the desired amplicon. For the samples of clam mantle tissue nodules, $\mathrm{C}_{\mathrm{T}}$ values were converted to estimated number of organisms based on the standard curve derived from serial dilution of pure QPX cultures. For marine aggregate and pseudofeces samples, the $C_{T}$ values were converted to estimated number of organisms based on the standard curve derived from the QPX-spiked marine aggregate series.

Histological analysis. H\&E stained tissue sections were evaluated histologically for location, severity of the inflammatory response, and number of live QPX organisms present in the section. Locations were qualified as focal, focally extensive, multifocal, or diffuse. Hemocytic inflammation was qualified as mild, moderate, or severe. Mild inflammation was represented by few hemocytes present in the section surrounding and engulfing QPX organisms (i.e. encapsulation/granuloma formation); moderate inflammation included encapsulation/granuloma walls composed of $\geq 20$ hemocytes or a solid focus of hemocytes $<1.3 \mathrm{~mm}$ in diameter; severe inflammation corresponded to encapsulation/granuloma walls $>20$ hemocytes thick or a solid focus of hemocytes $>1.3 \mathrm{~mm}$ in diameter. The total number of live QPX organisms (indicated by blue hematoxylin staining and lack of phagocytosis by hemocytes) was estimated for the organ examined and grouped into 1 of 5 categories (Category 0, no live or dead QPX organisms; Category 1, no live QPX organisms; Category $2,<10$ viable QPX organisms; Category 3,10 to 50 viable organisms; Category $4,>50$ viable organisms).

\section{RESULTS}

\section{Limit of detection}

The sensitivity of the QPX qPCR assay was determined using 10-fold serial dilutions of QPX cell cultures and marine aggregates spiked with serial dilutions of cultured QPX cell suspensions. Standard curves were generated by plotting the $C_{T}$ against the number of QPX organisms based on electronic particle counter analysis. In both cases, DNA from less than 3 organisms $(2.15 \pm 0.5)$ per reaction was detectable. This corresponded to the $10^{-4}$ dilutions from both the culture and QPX-spiked marine aggregates. The $10^{-5}$ dilution in the spiked marine aggregate series did not amplify and was below the lowest detection level for the electronic particle counter. Furthermore, using cultured QPX cell dilutions, the DNA from less than onefifth of a single organism per reaction was detected based on dilution of the extracted DNA and the standard curve formula. There was good correlation be- tween the amount of target template and $\mathrm{C}_{\mathrm{T}}$ value for both dilution series (Fig. 1).

\section{Specificity of assay}

A panel of 29 protist organisms suspected to belong to the class Labyrinthulomycetes (which includes labyrinthulids and thraustochytrids; Adl et al. 2005) was used to assess the specificity of the QPX real-time PCR assay (Table 1). To verify the phylogeny of these samples, general labyrinthulomycete primers based on SSU rDNA were used (Stokes et al. 2002). All isolate samples except CRSH-5/B3 and BC05Ca-18t were positive with the general labyrinthulomycete primers, indicating that 27 of the 29 strains were closely related to QPX. Only 1 of the 27 isolate samples (VA 1423-28) was positive using our qpxIRK primers. This isolate was also positive with QPX primers that targeted SSU rDNA (C. Audemard \& C. Dungan unpubl. data). The other 26 protist cultures did not amplify with the qpxIRK primers.

\section{QPX detection in environmental samples}

In order to evaluate the effectiveness of the QPX qPCR assay when detecting and quantifying parasite presence in the environment, several types of environmental samples were analyzed. These included DNA from gross tissue lesion samples (nodular inflammation in the mantle tissue) obtained from 4 of 16 clams, pseudofeces from all 16 clams, and marine aggregates from 41 of seawater collected from an area experiencing QPX-related clam mortalities. In our qPCR assay, the qpxIRK primers detected QPX in 3 of the 4 nodule samples. The estimated number of QPX organisms in the nodule samples ranged from 0 to approx. 3000 per sample (Table 2). All clams $(\mathrm{n}=16)$ were also examined histologically for the presence of QPX. Histology detected QPX in the 4 nodule samples (from clams 13, $14,15,16)$; however, Clam 16 contained only dead QPX organisms (Category 1 with regards to histology), corresponding to the absence of qPCR detection. Histological analysis also identified 3 other clams with QPX infections (clams 10,11, 12), but because there were no grossly observable nodules at the time of necropsy, there were no corresponding qPCR samples available for comparison (denoted as 'no nodule observed' in Table 2). The qPCR assay also detected QPX in 4 of the 16 pseudofeces samples analyzed. The estimated number of QPX organisms in pseudofeces samples ranged from 0 to 1700 per sample (Table 2). One of the 4 marine aggregate samples from Barnstable Harbor, Massachusetts also tested positive for the 
presence of QPX. In this sample, the assay detected DNA from the equivalent of less than 1 cell per reaction, or less than 25 QPX cells (range 10 to 24) in aggregated material settled out of 11 of seawater. This value corresponded to the lowest detected amount of QPX in any naturally infected environmental sample.

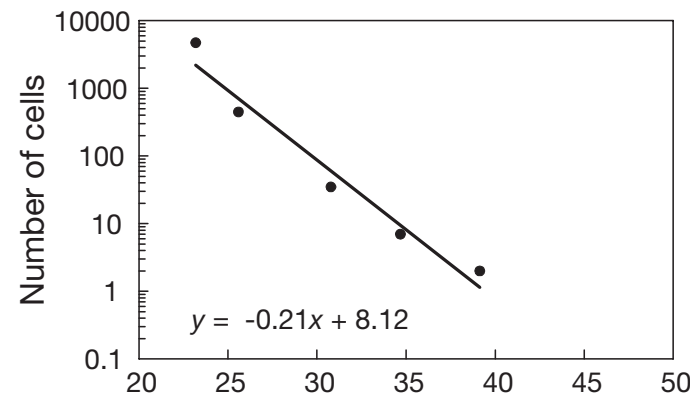

\section{DISCUSSION}

The infective dose required to cause QPX infections in clams in the environment has not yet been determined. A quantitative PCR assay that is both sensitive and specific for detecting QPX organisms is needed to

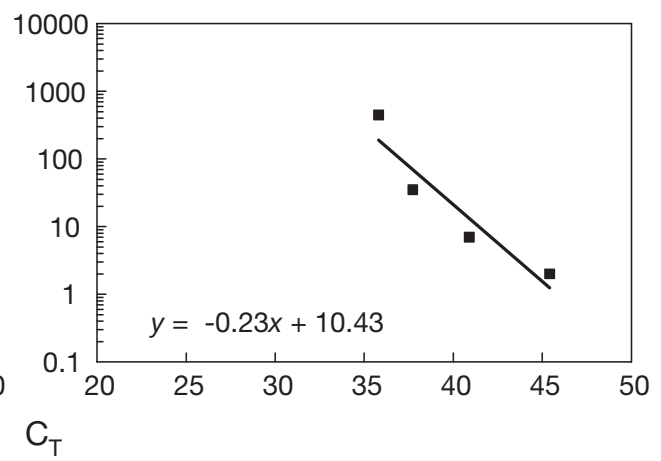

Fig. 1. Standard curves for Quahog Parasite X (QPX) culture (left; $\mathrm{r}^{2}=0.98$ ) and QPX-spiked marine aggregate suspensions (right; $\left.\mathrm{r}^{2}=0.94\right)$ using cell counts from an electronic particle counter. All samples were run in duplicate. $\mathrm{C}_{\mathrm{T}}$ : cycle threshold

Table 1. Thraustochytrid-like isolates used to assess specificity of qpxIRK primers for the qPCR assay. Labyrinthulomycete primers (Stokes et al. 2002) and qpxIRK primers (this study) were evaluated. QPX DNA was detected (i.e. + for both primer sets) in only the QPX culture (control) and isolate VA1423-28. Host species: Crassostrea virginica, Mercenaria mercenaria, C. ariakensis, and Mya arenaria; VA, Virginia; OR, Oregon

\begin{tabular}{|c|c|c|c|c|c|}
\hline Isolate code & Host species & Host source & $\begin{array}{l}\text { Host tissue } \\
\text { source }\end{array}$ & $\begin{array}{c}\text { Labyrinthulomycete } \\
\text { primers }\end{array}$ & $\begin{array}{l}\text { qpxIRK } \\
\text { primers }\end{array}$ \\
\hline CRSH-5/B3 & C. virginica & Chesapeake Bay & Hemolymph & - & - \\
\hline CRTW-1He/H11 & C. virginica & Chesapeake Bay & Hemolymph & + & _- \\
\hline 98MFS-6/A1 & C. virginica & Chesapeake Bay & Hemolymph & + & - \\
\hline VA1423-1 & M. mercenaria & Hog Island, VA & Mantle & + & - \\
\hline VA1423-2 & M. mercenaria & Hog Island, VA & Mantle & + & - \\
\hline VA1423-3 & M. mercenaria & Hog Island, VA & Mantle & + & - \\
\hline VA1423-4 & M. mercenaria & Hog Island, VA & Mantle & + & - \\
\hline VA1423-6 & M. mercenaria & Hog Island, VA & Mantle & + & - \\
\hline VA1423-10 & M. mercenaria & Hog Island, VA & Mantle & + & - \\
\hline VA1423-12 & M. mercenaria & Hog Island, VA & Mantle & + & - \\
\hline VA1423-15 & M. mercenaria & Hog Island, VA & Mantle & + & - \\
\hline VA1423-26 & M. mercenaria & Hog Island, VA & Mantle & + & - \\
\hline VA1423-28 & M. mercenaria & Hog Island, VA & Mantle & + & + \\
\hline VA1423-29a & M. mercenaria & Hog Island, VA & Mantle & + & - \\
\hline VA1423-29d & M. mercenaria & Hog Island, VA & Mantle & + & - \\
\hline VA1423-33 & M. mercenaria & Hog Island, VA & Mantle & + & - \\
\hline VA1423-37 & M. mercenaria & Hog Island, VA & Mantle & + & - \\
\hline BC05Ca-8t & C. ariakensis & Behai, China & Visceral mass & + & - \\
\hline BC05Ca-15t & C. ariakensis & Behai, China & Visceral mass & + & - \\
\hline BC05Ca-18t & C. ariakensis & Behai, China & Visceral mass & - & - \\
\hline BC05Ca-20t & C. ariakensis & Behai, China & Visceral mass & + & - \\
\hline $\mathrm{xMaC}-13 \mathrm{t}$ & M. arenaria & Yaquina Bay, OR & Labial palp, gill & + & - \\
\hline xMaC-19t & M. arenaria & Yaquina Bay, OR & Labial palp, gill & + & - \\
\hline xMaC-20t & M. arenaria & Yaquina Bay, OR & Labial palp, gill & + & - \\
\hline xMaD-10t & M. arenaria & Yaquina Bay, OR & Labial palp, gill & + & - \\
\hline xMaD-14t & M. arenaria & Yaquina Bay, OR & Labial palp, gill & + & - \\
\hline xMaD-18t & M. arenaria & Yaquina Bay, OR & Labial palp, gill & + & - \\
\hline xMaE-11t & M. arenaria & Yaquina Bay, OR & Labial palp, gill & + & - \\
\hline xMaE-13t & M. arenaria & Yaquina Bay, OR & Labial palp, gill & + & - \\
\hline QPX & M. mercenaria & Massachusetts & Culture & + & + \\
\hline
\end{tabular}


Table 2. QPX quantifications from environmental specimens from a QPXaffected field site. Estimated range of QPX cells based on standard curves. Nodule samples for qPCR analysis were only tested on clams where nodules sample was available for comparison (clams 1-12: no nodule observed). Histological key: extent of infection, severity of inflammation, category. Extent of infection: F, focal; E, focally extensive; M, multifocal. Severity of inflammation: M2, moderate; M3, severe. No. of organisms: Category 0, none; Category 1, no viable organisms; Category 2, <10 viable QPX organisms; Category 3, $10-50$ viable organisms; Category $4,>50$ viable organisms

\begin{tabular}{|lccc|}
\hline Clam & $\begin{array}{c}\text { Number of QPX cells } \\
\text { detected in clam } \\
\text { pseudofeces via qPCR }\end{array}$ & $\begin{array}{c}\text { Number of QPX cells } \\
\text { detected in clam nodule } \\
\text { (if present) via qPCR }\end{array}$ & $\begin{array}{c}\text { Histological } \\
\text { detection of } \\
\text { QPX in clam }\end{array}$ \\
\hline 1 & 0 & No nodule observed & 0 \\
2 & 0 & No nodule observed & 0 \\
3 & 0 & No nodule observed & 0 \\
4 & 0 & No nodule observed & 0 \\
5 & 0 & No nodule observed & 0 \\
6 & 0 & No nodule observed & 0 \\
7 & 0 & No nodule observed & 0 \\
8 & 0 & No nodule observed & 0 \\
9 & 0 & No nodule observed & 0 \\
10 & 0 & No nodule observed & E, M3, 4 \\
11 & $797-822$ & No nodule observed & F, M2, 0 \\
12 & $68-73$ & $800-805$ & F, M2, \\
13 & 0 & $2402-3037$ & F, M3, 4 \\
14 & $1030-1689$ & $49-72$ & M, M3, 4 \\
15 & $24-60$ & 0 & E, M3, 3 \\
16 & 0 & & F, M3, 1 \\
\hline
\end{tabular}
were observed during gross examination ( $\mathrm{n}=4$; clams 13-16); otherwise, no

particularly problematic with QPX because the thraustochytrids (i.e. the closest relatives to QPX) are ubiquitous yet taxonomically enigmatic. Thraustochytrids have been documented in coastal (Naganuma et al. 1998), oceanic (Raghukumar et al. 1990) and benthic (Santangelo et al. 2000) habitats, living on both plant (Sharma et al. 1994) and animal (Raghukumar 2002) substrates, but the number of DNA sequences available for comparison remains limited (Mo et al. 2002). The suite of thraustochytridlike isolates used in our study represents the best available current resource for comparison to QPX-like organisms, and thereby demonstrates specificity of the qpxIRK primer set to the target parasite.

For the qPCR assay described here, we targeted an expressed gene rather than ribosomal DNA in order to enhance specificity of the assay. Several assays targeting expressed genes have been developed for environmental pathogens (Gray et al. 2003, Guy et al. 2003, Panicker et al. 2004), includ-

advance research in this host (clam)-parasite (QPX) relationship. Sensitivity of the qPCR QPX assay was evaluated with serial dilutions of cultured cells to determine the lowest cell concentration yielding detectable parasite DNA. The particle counts from serial dilutions allow calibration to actual cell numbers, rather than to cell numbers inferred from theoretical dilution values. In addition, by quantifying the number of QPX cells in each dilution before template DNA extraction, the standard curves were generated without assumptions on the amount of DNA (i.e. gene copy number) contained in each cell. Lack of information on the number of gene copies per cell has limited other real-time PCR assays to qualitative (presence/absence) results (Bowers et al. 2000) or required researchers to estimate an average copy number per cell (Galluzzi et al. 2004). The QPX qPCR assay developed in this study detected DNA from less than 1 cell per reaction, which corresponds to less than 25 cells per aggregated material from 11 of seawater. This is comparable to other qPCR assays that detect the equivalent of 1 cyst or oocyst (Guy et al. 2003), and less than 100 cells per liter of water (Gray et al. 2003).

Specificity is more difficult to evaluate because it requires the demonstration that the primers in the qPCR assay do not detect (i.e. amplify) DNA from any organism other than the target organism (QPX). This is ing studies that directly demonstrated the improved effectiveness of targeting non-ribosomal DNA (Mollet et al. 1997, Dahllof et al. 2000). Of the 29 in vitro isolates from diverse, suspension-feeding molluscs that we tested, only 1 amplified with our qPCR assay. These results correspond with the observation that this isolate (VA 1423-28) also tested positive using PCR primers (Stokes et al. 2002) that target the SSU rDNA of QPX. This isolate was obtained from a clam collected within the documented range of the QPX parasite, and from a population of clams affected by QPX infections. However, because QPX cells did not readily proliferate in the primary isolate culture, the isolate was cryopreserved for posterity rather than fully expanded for cloning and taxonomic assessment.

To test the applicability of the newly developed qPCR assay, an assortment of environmental specimens from a QPX-affected field site were collected. Environmental samples included 16 clams, 4 of which possessed grossly observable inflammatory nodule lesions at the time of their necropsy. Nodules are often characteristic of a QPX infection (Smolowitz et al. 1998). Quantitative PCR analysis, corroborated with histological analysis, revealed that viable (i.e. live) QPX cells were present in 3 clams with nodules, and dead QPX cells were present in the other nodule sample. As expected, the dead QPX cells were not 
detected with qPCR (Clam 16). This result suggests that false positive readings would not be expected with the qPCR assay. For the 3 samples (Clams 13, 14, 15) with positive results from both $\mathrm{qPCR}$ and histology, the histological estimates of QPX cell numbers were lower than those of the new qPCR assay. This was also expected because the evaluated histological slide contained a $6 \mu \mathrm{m}$ section through the nodule, whereas the qPCR assay evaluated DNA from half a nodule.

Detection of QPX in marine aggregates and pseudofeces collected from a field site where QPX destroyed cultured clam populations shows that marine aggregates function as a reservoir for QPX (Lyons et al. 2005). Clams are suspension feeders, obtaining particles (including marine aggregates) from large volumes of seawater. Some of the particles are ingested and some are rejected (Ward \& Shumway 2004). In hard clams, those particles that are ingested are shuttled to the mouth while those that are rejected are collected (i.e. production of pseudofeces) at the base of the inhalant siphon until periodically ejected (Grizzle et al. 2001). The base of the inhalant siphon is also where the characteristic nodules are prevalent (Smolowitz et al. 1998), indicating that the tissue at the base of the siphon is a portal of entry for QPX and that rejection of marine aggregates is a mechanism of pathogen cell delivery. The relatively higher numbers detected in the pseudofeces samples $\left(10^{2}\right.$ to $\left.10^{3}\right)$ compared with the marine aggregate sample $\left(10^{1}\right)$ are not surprising, given that production of pseudofeces concentrates particles obtained from the environment.

The development of the QPX disease is relatively slow, with gross signs of infection not appearing for 3 to $6 \mathrm{mo}$ in laboratory experiments (R. Smolowitz unpubl. data) and over $1 \mathrm{yr}$ in the field (Smolowitz et al. 1998). The results from the analysis of clam tissue (via histology) and pseudofeces (via qPCR) samples demonstrate all of our hypothesized developmental stages of the infection sequence, including negative clams with negative pseudofeces (Clams 1 to 9), negative clams with positive pseudofeces (Clams 11, 12), and positive clams with positive pseudofeces (Clams 14, 15). In addition, there were positive clams with negative pseudofeces (Clams 10,13). Although the pseudofeces in the positive clam samples were not the pseudofeces directly responsible for the infection (the infection would have occurred prior to the sampling date), the sequence supports the hypothesis that pseudofeces formation is involved in transmission of QPX infections.

Future research efforts are required to fully understand the physiological relevance of QPX presence in the environment and the onset of the QPX disease. Such studies will require an interdisciplinary approach using comprehensive diagnostic and sam- pling technologies. The qPCR assay described in the current study will be a valuable tool to study QPX transmission and to improve diagnoses in clams. Samples evaluated in this analysis included (1) serially diluted cultured QPX cells, (2) QPX-spiked marine aggregates, (3) marine aggregates collected from QPX-affected field sites, (4) nodules from clams collected from QPX-affected field sites, (5) pseudofeces from clams collected from QPX-affected field sites, and (6) thraustochytrid-like cultures isolated from suspension-feeding bivalves. Results from these samples demonstrate that this new qPCR assay for QPX is both sensitive and specific for analyses of QPX cells in environmental samples.

Acknowledgements. We thank C. Romano and K. Uhlinger (Marine Biological Laboratory) for laboratory assistance, $\mathrm{T}$. Marcotti (Town of Barnstable, Massachusetts) for field collection assistance, and R. Gast (Woods Hole Oceanographic Institution) for use of an inverted microscope. We also appreciate the competent work of R. Hamilton (Maryland Department of Natural Resources) in propagating, cloning, and cryopreserving labyrinthulid isolates from molluscs. In addition, we gratefully acknowledge C. Audemard (Virginia Institute of Marine Science) for generous permission to cite unpublished results of PCR assays on labyrinthulid isolates. This research was funded in part by NSF-NIH Ecology of Infectious Disease Grant (No. 0429018) to R.S. and a grant to R.S. and S.B.R. from the County of Barnstable, Massachusetts.

\section{LITERATURE CITED}

Adl SM, Simpson AGB, Farmer MA, Andersen RA and 24 others (2005) The new higher level classification of eukaryotes with emphasis on the taxonomy of protists. J Eukaryot Microbiol 52:399-451

Anderson RS, Kraus BS, McGladdery SE, Reece KS, Stokes NA (2003) A thraustochytrid protist isolated from Mercenaria mercenaria: molecular characterization and host defense responses. Fish Shellfish Immunol 15:183-94

Audemard C, Reece KS, Burreson EM (2004) Development of real-time PCR for the detection and quantification of the protistan parasite Perkinsus marinus. Appl Environ Microbiol 70:6611-6618

Bowers HA, Tengs T, Glasgow HB, Burkholder JM, Rublee PA, Oldach DW (2000) Development of real-time PCR assays for rapid detection of Pfiesteria piscicida and related dinoflagellates. Appl Environ Microbiol 66: 4641-4648

Dahllof I, Baillie H, Kjelleberg S (2000) rpoB-based microbial community analysis avoids limitations inherent in 16S rRNA gene intraspecies heterogeneity. Appl Environ Microbiol 66:3376-3380

Dove A, Bowser PR, Cerrato RM (2004) Histological analysis of an outbreak of QPX disease in wild hard clams Mercenaria mercenaria in New York. J Aquat Anim Health 16: $246-250$

Drinnan RE, Henderson EB (1963) 1962 mortalities and a possible disease organism in Nequac quahogs. Annual Report No. B11, Biological Station, St. Andrews, New Brunswick

Dungan CF, Hamilton RM (1995) Use of tetrazolium-based cell proliferation assay to measure effects of in vitro condi- 
tion on Perkinsus marinus (Apicomplexa) proliferation. J Eukaryot Microbiol 42:379-388

Galluzzi L, Penna A, Bertozzini E, Vila M, Garces E, Magnani M (2004) Development of a real-time PCR assay for rapid detection and quantification of Alexandrium minutum (a dinoflagellate). Appl Environ Microbiol 70:1199-1206

Gray M, Wawrik B, Paul J, Casper E (2003) Molecular detection and quantitation of the red tide dinoflagellate Karenia brevis in the marine environment. Appl Environ Microbiol 69:5726-5730

Grizzle RE, Bricelj VM, Shumway SE (2001) Physiological ecology of Mercenaria mercenaria. In: Kraeuter JN, Castagna M (eds) Biology of the hard clam. Elsevier, Amsterdam, p 305-382

Guy RA, Payment P, Krull UJ, Horgen PA (2003) Real-time PCR for quantification of Giardia and Cryptosporidium in environmental water samples and sewage. Appl Environ Microbiol 69:5178-5185

Howard DW, Lewis EJ, Keller BJ, Smith CS (2004) Histological techniques for marine bivalve mollusks and crustaceans. NOAA Tech Memo NOS-NCCOS 5

Kleinschuster SJ, Smolowitz R, Parent J (1998) In vitro life cycle and propagation of Quahog Parasite Unknown. J Shellfish Res 17:75-78

Lyons MM, Ward JE, Smolowitz R, Uhlinger KR, Gast RJ (2005) Lethal marine snow: pathogen of bivalve mollusc concealed in marine aggregates. Limnol Oceanogr 50:1983-1988

Maas PAY, Kleinschuster SJ, Dykstra MJ, Smolowitz R, Parent J (1999) Molecular characterization of QPX (quahog parasite unknown), a pathogen of Mercenaria mercenaria. J Shellfish Res 18:561-567

Marchler-Bauer A, Anderson JB, Cherukuri PF, DeWeeseScott C and 20 others (2005) CDD: a Conserved Domain Database for protein classification. Nucleic Acids Res 33:D192-6

Mo C, Douek J, Rinkevich B (2002) Development of a PCR strategy for thraustochytrid identification based on $18 \mathrm{~S}$ rDNA sequence. Mar Biol 140:883-889

Mollet C, Drancourt M, Raoult D (1997) rpoB sequence analysis as a novel basis for bacterial identification. Mol Microbiol 26:1005-1011

Myers ML, Panicker G, Bej AK (2003) PCR detection of a newly emerged pandemic Vibrio parahaemolyticus O3:K6 pathogen in pure cultures and seeded waters from the Gulf of Mexico. Appl Environ Microbiol 69:2194-2200

Editorial responsibility: Richard J. Cawthorn, Charlottetown, Prince Edward Island, Canada
Naganuma T, Takasugi H, Kimura H (1998) Abundance of thraustochytrids in coastal plankton. Mar Ecol Prog Ser 162:105-110

Panicker G, Myers ML, Bej AK (2004) Rapid detection of Vibrio vulnificus in shellfish and Gulf of Mexico water by realtime PCR. Appl Environ Microbiol 70:498-507

Ragan MA, MacCallum GS, Murphy CA, Cannone JJ, Gutell RR, McGladdery SE (2000) Protistan parasite QPX of hardshell clam Mercenaria mercenaria is a member of Labyrinthulomycota. Dis Aquat Org 42:185-190

Raghukumar S (2002) Ecology of the marine protists, the Labyrinthulomycetes (Thraustochytrids and Labyrinthulids). Eur J Protistol 38:127-145

Raghukumar S, Raghukumar C, Rajendran A (1990) Abundance of thraustochytrid fungi in the Arabian Sea. Estuar Coast Shelf Sci 31:251-358

Ragone-Calvo LM, Walker JG, Burreson EM (1998) Prevalence and distribution of QPX, Quahog Parasite Unknown, in hard clams, Mercenaria mercenaria in Virginia, USA. Dis Aquat Org 33:209-219

Santangelo G, Bongiorni L, Pignataro L (2000) Abundance of thraustochytrids and ciliated protozoans in a Mediterranean sandy shore determined by an improved, direct method. Aquat Microb Ecol 23:55-61

Sharma S, Raghukumar C, Raghukumar S, Sathe-Pathak V, Chandramohan D (1994) Thraustochytrid and fungal component of marine detritus. II. Laboratory studies on decomposition of the brown alga Sargassum cinereum. J Exp Mar Biol Ecol 175:227-242

Smolowitz R, Leavitt D, Perkins F (1998) Observations of a protistan disease similar to QPX in Mercenaria mercenaria (hard clams) from the coast of Massachusetts. J Invertebr Pathol 71:9-25

Stokes NA, Ragone-Calvo LM, Reece KS, Burreson EM (2002) Molecular diagnostics, field validation, and phylogenetic analysis of Quahog Parasite Unknown (QPX), a pathogen of the hard clam Mercenaria mercenaria. Dis Aquat Org 52:233-247

Ward JE, Shumway SE (2004) Separating the grain from the chaff: particle selection in suspension- and deposit-feeding bivalves. J Exp Mar Biol Ecol 300:83-130

Whyte SK, Cawthorn RJ, McGladdery SE (1994) QPX (Quahaug Parasite X), a pathogen of northern quahaug Mercenaria mercenaria from the Gulf of St. Lawrence, Canada. Dis Aquat Org 19:129-136

Submitted: March 20, 2006; Accepted: July 12, 2006

Proofs received from author(s): September 8, 2006 